（日本水花研究所）（昭和 10 年 4 月 15 日受理）

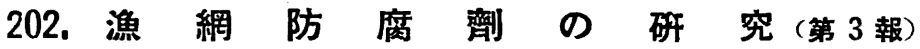 \\ 數種の銅化合物を油性防腐劑中に添加したる場合の \\ 化合物の種類の防腐カに及ほす影響に就て
}

\author{
村 田正 雄
}

本報に於ては試驗日數を 280 日まで延長し, 試料としてュールタールに硫酸銅, 亞䂤酸銅, 第 2 酸化銅,

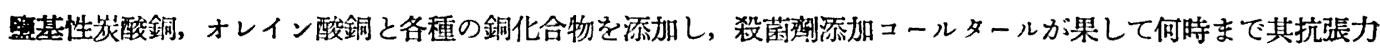
を持續するものなるかを確かめると同時に，銅化合物の中にて如何なる化合物が有效なるかをも知らんとして

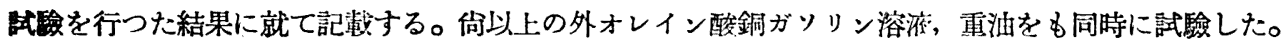

實驗

1. 圾駼方法及堨所 第 1 及 2 報と同栐である。

2. 供試材料継 綿絲, 20 番手 60 本合せ, マニラ䟽絲, 1.3 多絲

\section{3. 供試染料調繁材料}

コールタール 八嶓製鐵所製品, 比重 1.185 , 粘度 $60^{\circ} \mathrm{C}$ に於けるレッドゥッド秒數 85 秒 硫酸銅，亞砒酸銅，第 2 酸化銅は局方を，䲆基性岑酸銅は化學用を使用し，硫酸銅は加熱して結晶水を追出 し㸮末とし，他は乾燥して粉末として用ひた。

オレイン酸銅 不二塗料彆造所製

\section{4. 供訊杂料種類及其調製法}

$$
\begin{aligned}
& \text { 番㫘染 料 名 } \\
& 1 \text { コールタール } \\
& 2 \text { エールタール十硫酸銅 } \\
& 3 \text { コールタール十亞砒酸銅 } \\
& 4 \text { コールタール十第 } 2 \text { 酸化銓 } \\
& 5 \text { コールタール十警基性炭酸銅 } \\
& 6 \text { コールタール十オレイン酸銅 } \\
& 7 \text { オレイン酸銅ガソリン溶液 }
\end{aligned}
$$

8 重 油
調製法 加熱し結晶水を脫水し粉末としたるものを $5 \%$ (重量)添加 乾燥せる粉末を $5 \%$ (重量) 添加 乾燥せる枌末を $5 \%$ (重量) 添加 乾燥せる粉末を $5 \%$ (重量) 添加 オレイン酸铜を $5 \%$ (重量) 添加 ガソリンに對してオレイン酸銅を $20 \%$ (重量)溶僻す，ガソリン は黑貝印 㵠地不明市販品

5. 染付に依る重量增加率 染付前後の目方の差を染付前の重量で除した值を 100 倍した數を以て表した。

番㩆 染料名

1 エールタール

2 エールタール十硫飘銅

3 コールタール十亞砒酸銅

4 コールタール十第 2 酸化銅 綿絲 $\checkmark=5$ 旅絲|番號 染 料 名

$138 \quad 48$

$180 \quad 57$

$175 \quad 59$

174
59

62
5

コールタールトオレイン酸铜 157

7 オレイン酸銅ガソリン溶液

8 重油
綿絲 マニラ栕絲

$173 \quad 57$

$157 \quad 68$

$34 \quad-$

$69 \quad 24$

ュールタールに上記の各種殺菌䝆の粉末を添加すると相當に粘度を增大寸るが，之は染料の附着程度にも現 はれてるてコールタールに比べて何れも多く附着して居る。コールタールにオレイン酸銅を加へたものは他の

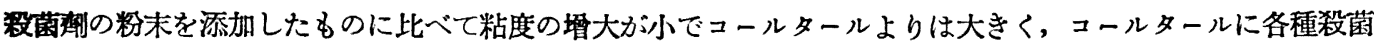
利の粉末を添加したものよりは小さい附着率を示して居る。只之のマニラ腋絲に對する附着率か㑢つて他より 
大きいのは理論通りになつてるない點で染付時の何等かの作用で斯の如き變哄を來したものであらら。

6. 莯張力溉定結果 (單位 lbs)

(1) 綿 絲

\begin{tabular}{|c|c|c|c|c|c|c|c|c|c|c|}
\hline$\frac{\text { 測定月日 }}{\text { 浸清日 }}$ & $\left.\begin{array}{l}3 \\
3 \\
12 \text { 日 }\end{array}\right)$ & $\begin{array}{ll}4 & \text { 月 } \\
1 & \text { 日 }\end{array}$ & $\begin{array}{ll}5 & \text { 月 } \\
1 & \text { 日 }\end{array}$ & $\begin{array}{c}5 \text { 月 } \\
31 \text { 昌 }\end{array}$ & $\begin{array}{l}7 \text { 㝵 } \\
6 \text { 日 }\end{array}$ & $\begin{array}{l}8 \text { 月 } \\
10 日\end{array}$ & $\begin{array}{l}9 \text { 月 } \\
14 \text { 日 }\end{array}$ & $\begin{array}{l}10 \text { 月 } \\
19 \text { 日 }\end{array}$ & $\begin{array}{l}11 \text { 月 } \\
18 \text { 日 }\end{array}$ & $\begin{array}{l}12 \text { 月 } \\
18 \text { 日 }\end{array}$ \\
\hline 番號 數 & 0 & 20 & 50 & 80 & 115 & 150 & 185 & 220 & 250 & 280 \\
\hline 素＼cjkstart絲 & 67.9 & 59.9 & 12.5 & - & - & - & - & - & - & - \\
\hline 1 & 64.9 & 54.5 & 46.8 & 54.4 & 46.8 & 19.4 & 16.0 & - & - & - \\
\hline 2 & 66.0 & 54.3 & 53.1 & 50.6 & 51.0 & 49.8 & 58.2 & 63.8 & 70.9 & 67.3 \\
\hline 3 & 62.7 & 52.2 & 49.4 & 50.1 & 49.4 & 48.9 & 62.6 & 68.8 & 70.0 & 69.1 \\
\hline 4 & 64.2 & 54.6 & 50.1 & 53.3 & 49.0 & 50.1 & 55.3 & 67.3 & 69.0 & 67.0 \\
\hline 5 & 61.1 & 52.6 & 50.8 & 49.1 & 50.8 & 48.6 & 58.0 & 66.3 & 70.4 & 66.5 \\
\hline 6 & 52.5 & 53.6 & 49.4 & 54.8 & 56.2 & 51.5 & 63.4 & 65.4 & 60.0 & 56.0 \\
\hline 7 & 62.8 & 65.1 & 66.6 & 41.0 & 28.0 & 189 & 7.0 & - & - & - \\
\hline 8 & 68.4 & 73.8 & 69.9 & 8.4 & - & - & - & - & - & - \\
\hline
\end{tabular}

(2) $\boldsymbol{\nabla}$ 二 5 麻絲

\begin{tabular}{|c|c|c|c|c|c|c|c|c|c|c|}
\hline 浸漬日 & $\left(\begin{array}{cc}3 & \text { 月 } \\
12 & \text { 月 }\end{array}\right)$ & $\begin{array}{ll}4 & \text { 月 } \\
1 & \text { 昌 }\end{array}$ & $\begin{array}{ll}5 & \text { 月 } \\
1 & \text { H! }\end{array}$ & $\begin{array}{l}5 \text { 月 } \\
31 \text { 日 }\end{array}$ & $\begin{array}{r}7 \text { 月 } \\
6 \text { 日 }\end{array}$ & $\begin{array}{l}8 \text { 月 } \\
10 \text { 日 }\end{array}$ & $\begin{array}{l}9 \text { 月 } \\
14 \text { 日 }\end{array}$ & $\begin{array}{l}10 \text { 月 } \\
19 \text { 日 }\end{array}$ & $\begin{array}{l}11 \text { 月 } \\
18 \text { 日 }\end{array}$ & $\begin{array}{l}12 \text { 月 } \\
18 \text { 昌 }\end{array}$ \\
\hline 番碞 & 0 & 20 & 50 & 80 & 115 & 150 & 185 & 220 & 250 & 280 \\
\hline 素 絲 & 133.5 & 112.7 & 38.6 & 15.5 & - & -. & - & - & - & - \\
\hline 1 & 143.8 & 140.8 & 135.7 & 123.9 & 68.2 & 48.9 & 45.6 & 29.6 & 25.4 & 15.0 \\
\hline 2 & 135.3 & 138.1 & 143.5 & 153.6 & 136.5 & 93.6 & 81.7 & 45.0 & 34.0 & 27.9 \\
\hline 3 & 136.8 & 145.1 & 141.3 & 153.3 & 149.2 & 128.3 & 106.3 & 69.1 & 60.9 & 31.4 \\
\hline 4 & 136.1 & 146.8 & 137.5 & 143.3 & 156.1 & 125.6 & 134.9 & 88.3 & 70.1 & 50.6 \\
\hline 5 & 139.1 & 150.6 & 162.5 & 132.3 & 142.6 & 106.4 & 82.3 & 53.4 & 41.9 & 12.4 \\
\hline 6 & 126.8 & 151.0 & 136.6 & 142.1 & 137.6 & 91.4 & 81.1 & 68.5 & 36.6 & 25.2 \\
\hline 7 & 147.5 & 156.6 & 145.5 & 99.9 & 58.8 & 13.9 & 16.1 & - & - & 一 \\
\hline 8 & 154.6 & 163.5 & 74.3 & 25.6 & - & - & - & - & - & - \\
\hline
\end{tabular}

\section{7. 試駧結果に就て}

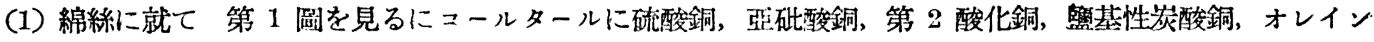
第 1 阅綿絲に對する成縝

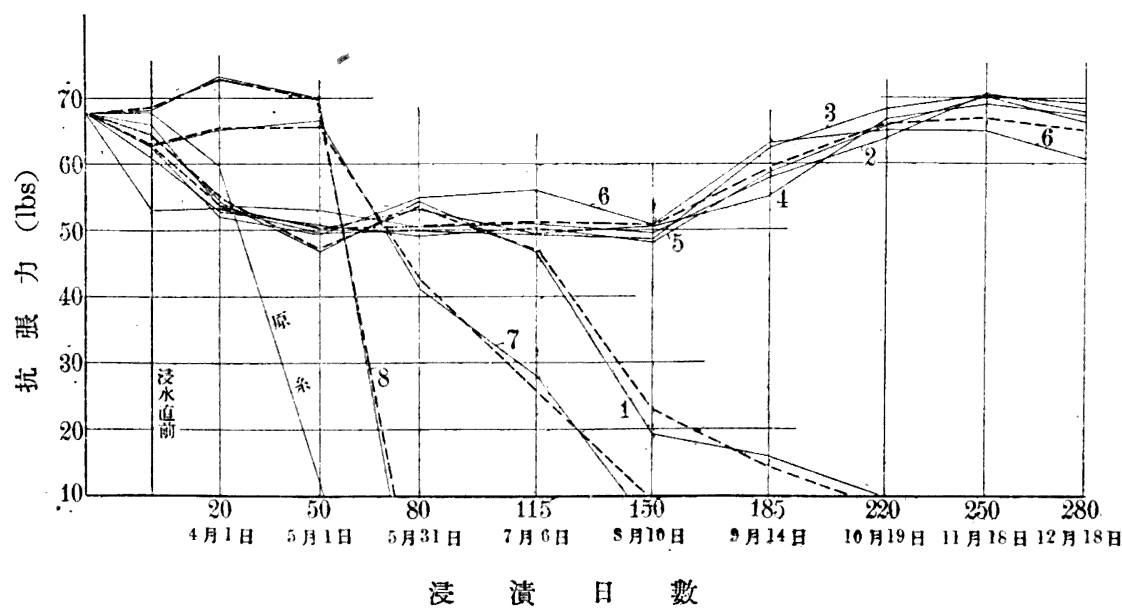

酸銅を加へたものは殆ど同栐の成績を示し核漬後一旦少しく弱くなり當分其の狀態を續け，150 日前後の當り 
からぼつぼつ抗張力を嘼大し始め 250 日目當りで逐に最初の抗張力よりも極僅か乍ら强い程度になり, 其後は 漸次降下寸る樣な傾向を示して居る。浸漬後一旦少しく弱くなり試驗の終りに近くなつて再び强くなることは 第 2 報にて報告した試驗結果とよく一致して居る。又試驗の時期から見れば第 1 報の試驗と今包の試驗とは 略同一であつて其爲か本試驗の 150 日目當り迄の成績は第 1 報の成績に餘程舆く似て居る。郎ち第 1 報の試 驗では之から抗張力を增大しようと云ふ所で試驗が終つたので, 遂に此の一旦弱くなつたものか再び强くなる と云ふ現象を見逃した譯である。以上の成績から添加殺菌劑は同じ銅化合物であれば化合物の種類には殆ど關 係しない事が判る。即ち化合物の種類に㑈て生ずる各種物理的乃至化學的作用の變化は問題でないことにな る。依て實際の場合には銅化合物の內で最も安價な硫酸銅を燒いて結晶水を除去して用ふればよいことにな る。オレイン酸銅を加へたものは他の銅化合物の粉未を加へたものに比較して試驗の前牛期に於ては多少成績 良く, 後牛期に至つて稍々劣る點は第 2 報の試驗結果と似て居るが其差の程度は今包の 試驗結果の方が可成 り少い樣である。之は第 2 報に於てはュールタール8, クレオンート2(容量) の割合に混合したものを原油 として用ひたに對し，今包の試驗ではコールタールを原油として居る篇ではないかと考へられる。郎ち第 2 報 の試驗では原油にクレオンートが入つて居る篇に浸漬試驗中にクレオソートが流失し, クレオソートと共にオ レイン酸銅をも流失する爲に其差が大きく出たものと解せられる。オレイン酸銅をガソリンに溶解したものは 稌程早く腐敗して居る。重油も其儘では殆ど問題にならない。

（2） マニラ麻絲に就て 第 2 圖を見るに略第 2 報の試驗結果に類似の成績となつてるる。郎ちコールター ルに各種殺菌凮を加へたものは絹絲の場合の樣に一旦弱くなつたものが再び强くなる樣な現象はないが份相當

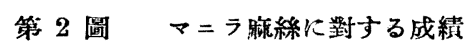

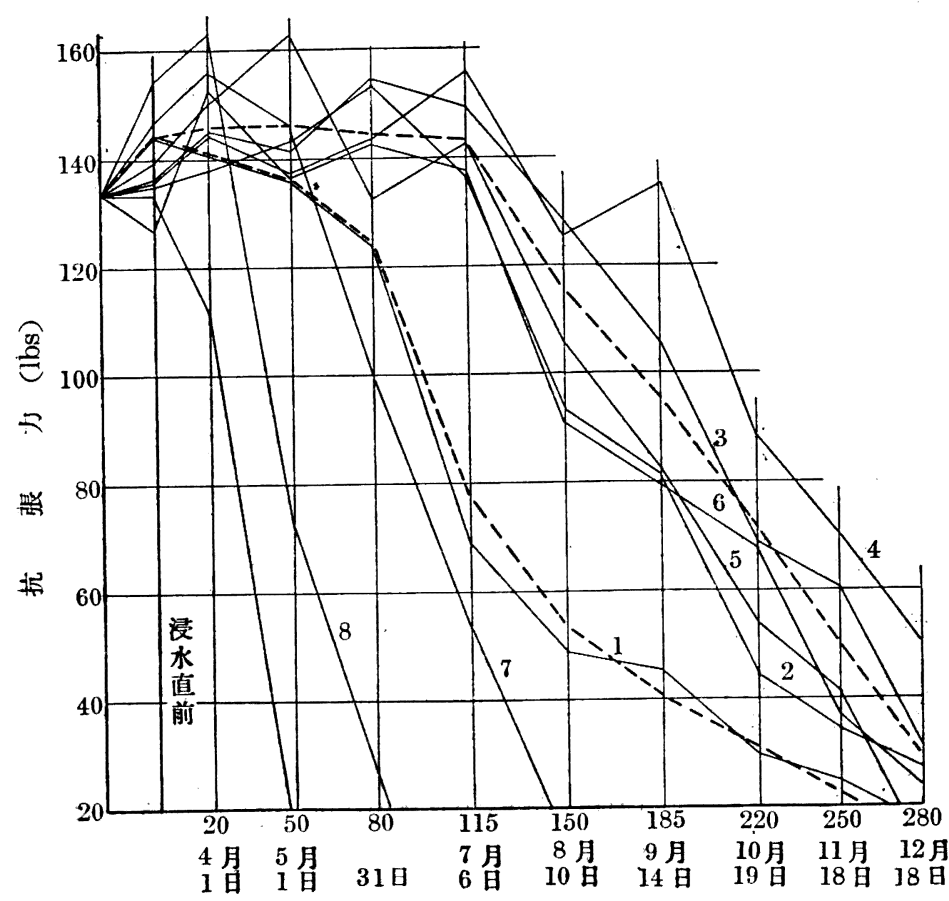

浸 漬 日 數 な成樍を示して居る。綿絲の場 合と違つて添加殺菌劑の 種類に 依て多少の差が窺はれる。郎ち 亞砒酸銅，第 2 酸化銅添加のも

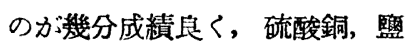
基性炭酸銅，オレイン酸銅を加 へたものは何れも稍劣つて居 る。亞砣酸銅の方が硫酸銅より も稍成樍良好なことは第 2 報の 試驗でも見られる所であつて偶 然の一致でもない樣にも考へら れるが，何れにせよ大した差で はない。オレイン酸銅添加のも のは綿絲の場合に述べた如く， 本試驗に於ては原油にクレォン ートが入つなない䉆とマニラ 麻絲に對しては染付に依る重量 增加率が他に比べて小なるべき 
筈のものか稍大となつてるる事の䉆に比較的良好な成績を示したるのと考へられるっオレイン酸銅ガソリン溶 液及び重油は殆ど問題にならない成績である。

以上 3 四の試驗に体りコールタールヌは之にクレォンートを混合した油に各種有毒金屬化合物, 主として 銅化合物を添加したるのは綿絲及マニラ麻絲に對して原油に比べて著しく大なる防腐效力を發揮することが判 り，又綿絲に對しては以上の如き浸漬試驗に於ては一旦弱くなつたものが再び强くなると云ふ未だ且て發見さ れてるない面白い現象のあること，同一量を添加した場合オレイン酸銅を添加したものよりも銅化合物の粉末 を加へた方が幾分成績良好であり且つ水流の影響を受けることの少い事, 浸漬試驗に於ては抗張力の變化に對 して水溫が相當に影響すること等を知り得た。綿絲に對しては都合 3 回試驗しマニラ麻絲に對しては 2 四試 驗した事になり先づ大體の成績は知り得た譯である。笛以上の試驗では主として銅化合物に就て試驗したので あるが其の他水銀, 亞鉛, 鉛, 其他の有機性金犀化合物等に就ても試驗してみたら面白い結果が得られる事と 思ふ。 又之等の殺菌劑をコロイドにして油に加へる事も面白い方法と考へられ，著者も之等の點に就て多少貿 驗を行つてみたが，未だ充分綎つてみないので一先づ上の分のみを報告した次第である。斯くして漁網の防 腐劑は次第に船底塗料の研究に近づきつ」ある樣であつて, 兩者を平行して試驗して行つたら又新しい方面が 開けて來るのではあるまいか。

總括

1. コールタールに硫酸銅，亞砒酸銅，第2 酸化銅、暨基性炭酸銅，オレイン酸銅を加へたもの，オレイン 酸銅ガソリン溶液, 重油の綿絲及マニラ麻絲に對する防隃效力の比較試驗を行つた。

2. 以上の各種銅化合物をコールタールに加へたものは何れも著しく其防腐效力を增大寸る。然して其效果 は源加銅化合物の種類にはあまり影響しない樣である。

3. 以上の各種銅化合物を涯加したコールタールは綿絲に對しては第 2 回の試驗と同樣一旦弱くなつたも のが再ひ强くなると云ふ現象を現はして居る。

4. マニラ麻絲に對しては綿絲の場合の如く一旦弱つたものが再び强くなる樣な現象はないが，杽菌劑を添 加したものは涯加しないるのに比ぶれば何れも相當の成績を示して居る。

5. 以上の 3 四の試驗でコールタールヌは之にクレオソートを混合したものに备種有䔦金屬化合物,主とし て銅化合物を添加したものが綿絲並にマニラ麻絲に對して著しく其防腐效力を增大することを確めたのである が，銅化合物のみならず水銀，亞鉛，鈶，其他有機金虽化合物等に就て，又それ等のコロイド就ても試驗し てみたら面白い結果が得られるのではないかと思はれる。

附記 以上の方法は第 95174 號を以て特䛸せられ, 目下日本漁網船具株式會社に於て嘪用化せられて居る。本 研究は著者が日本㴔網船具株式會社研究部在任中に行つたもので, 本發表を御許可下さつた日本㴔絧船具株式会社 並に研究上多くの御助言を賜つた故槑原鑑司博士及び小会善平氏に謝意を表すると共に 助手中村圭介君の第を感 謝する。 